Review

\title{
Engaging Employees with Good Sustainability: Key Performance Indicators for Dry Ports
}

\author{
Felix Kin Peng Hui * ${ }^{(1)}$, Lu Aye ${ }^{(1)}$ and Colin F. Duffield $(\mathbb{D}$ \\ Department of Infrastructure Engineering, The University of Melbourne, Melbourne, VIC 3010, Australia; \\ lua@unimelb.edu.au (L.A.); colinfd@unimelb.edu.au (C.F.D.) \\ * Correspondence: huik1@unimelb.edu.au
}

Received: 27 April 2019; Accepted: 21 May 2019; Published: 24 May 2019

\begin{abstract}
Dry ports have the potential to enhance the sustainability of transport systems, yet their introduction requires major changes to the current logistics chain. Further, emphasising sustainability goals and continued employee engagement can be a challenge when developing or implementing organisational change management programs in dry ports. Key considerations include governmental requirements and compliance, investor expectations, as well as employee engagement; these factors may be conflicting. The top-down management approach supported by strong leadership, participative approaches and constant communication assists in achieving successful change management. Sound selection of key performance indicators (KPIs) provides a set of metrics to track and aid the change process. They serve as a unifying link between top managements' sustainability goals and employees' engagement. The initial findings of our research confirm that both port and terminal operators have a gap in their understanding of the importance of sustainability goals and environmental goals. This will have a flow-on effect of port and terminal operators not driving the right messages to their staff in their organisational change management programs. Based on a critical literature review, it has been established what might qualify as good sustainability KPIs for dry ports. An example of a dry port at the Port of Somerton has been included. As every dry port has different requirements and constraints, it is important to develop KPIs together with stakeholders.
\end{abstract}

Keywords: sustainability; performance indicators; dry ports; engagement

\section{Introduction}

A dry port with rail connectivity from a seaport, complete with intermodal facilities, enables the movement of goods to trucks or nearby warehouses and has the potential to expand the volumes of existing seaports. Seaports that are located close to big cities also benefit from having trucks routing through outer areas since the cargoes are shifted to go to the intermodal stations by rail. Environment improvements follow as goods are moved more efficiently. Dry ports can also be seen as fulfilling the functions of the broader supply chain. UNESCAP (2006) [1] classified different levels of logistical activities of the dry port within the supply chain of any goods. At the lowest level, dry ports can incorporate container yards, container depots that may include customs clearance. At a higher level, dry ports may include additional logistic functions and value-added activities. At the highest level, dry ports may become a processing zone. An example would be an industrial estate. Close-range dry ports help alleviate problems within the supply chain by overcoming problems in land shortage, traffic congestion and environmental problems [2] (Nguyen and Notteboom 2019). Mid-range dry ports act as consolidation points for different railway lines and services when the supply chain is spread over a large geographic area [3] (Beresford et al. 2012).

With dry ports operating as part of a wider supply chain, sustainability is an important concept that needs the support and buy-in from everyone working in the dry ports. So how do dry ports 
translate sustainability initiatives and programs into success stories? The key idea is that sustainable goals can be actionable only if these goals or key performance indicators (KPIs) are meaningful to the employees working in the dry port. By making these KPIs more meaningful, employees are more likely to be engaged in helping dry ports achieve these sustainable goals. This paper examines the structure of dry ports, how environmental sustainability can be quantified, and what makes for meaningful targets that employees in dry ports can understand. The following section is a detailed literature of dry ports and how dry ports help to improve the performance and sustainability of the seaports with which they are linked. This section will also contain a discussion on how sustainability is quantified in dry ports. This is followed by a review of the literature involved in turning these into goals and key performance indicators and how employees can be engaged with meaningful goals. This is followed by a detailed discussion on the gaps and challenges and an example of a dry port in Melbourne.

\section{Literature Review}

\subsection{What are Dry Ports?}

A dry port (or inland port) is an inland intermodal station that is directly connected to a seaport. This arrangement allows shippers to collect or leave their cargoes at the intermodal station. Services such as storage, maintenance and cleaning of containers, and customs clearance are available at the dry port with the same level of service as the seaport. The use of dry ports frees up important land space around the seaport (Roso, Wonxeius and Lumsden 2009) [4].

Roso and Lumsden (2009) [5] argued that dry ports only benefit those seaports that are constrained by a shortage of land or access. The idea of expanding inland is a way of extending a port's cargo handling abilities, as well as its connectivity to the hinterland. Implementing dry ports eliminates queues at the seaports, resulting in time savings in the supply chain. The change from moving goods by trucks to moving goods on rail also makes possible gains in reduced environmental impacts as a single train trip can substitute for 35 trucks. This is an especially important consideration for organisations attempting to embed more environmentally conscious practices in their supply chain management. Intermodal rail plays a very important role in organisations' efforts to go green without added expense, accounting for only $2.5 \%$ of transportation-based greenhouse gas (GHG) emissions. In the U.S.A, a single double-stack train alone translates into the removal of 300 trucks from highways (US EPA 2014) [6].

Seamless transportation and faster movement of goods will impact a port's competitiveness. This will also improve a seaport's access to the market. The implementation of dry ports influences the physical and administrative flows of the seaport, possibly reducing much of the work done at the seaport. It is also important to recognise that not all activities can be transferred inland, such as loading and unloading onto the ship.

New dry ports need to have terminals sited inland. The physical and administrative workflows being shifted inland will also have the effect of creating new jobs in the suburbs or locations where they are sited. Without the constraint of space, the new inland terminals can also have co-located activities, such as storage, warehousing and business parks; for example, the Cube Business Park (2018) in Moorebank Intermodal Station and the Somerton Business Park (2018). Roso, Brnjac and Abramovic (2015) [7] showed that the key considerations in the selection of the site for a dry port terminal location are a good flow followed by a spatial criterion. In most cases, these new facilities must blend into the surrounding areas (Roso and Lumsden 2009) [5]. Nunez et al. (2013) [8] argued that the selection of a dry port is a geographical multi-disciplinary problem with significant economic, social and environmental implications.

Wiegmans, Witte and Spit (2015) [9] analysed major European dry ports and found that the success of many dry ports is driven by the presence of a container terminal, the ability to handle a diverse range and specific types of goods, and the accessibility of the dry port relative to the regional motorway network. These are important factors in explaining the size and growth of dry ports. 


\subsection{Performance and Sustainability of Dry Ports}

The World Bank developed a set of metrics for measuring the performance of ports in general, known as the Logistics Performance Index (LPI). The LPI of ports is a macroeconomic indicator used to help aggregate data into one standard indicator. However, this measure is focused on productivity measures with measures for sustainability being a small component of the key performance indicators (KPIs). The LPI is a weighted average score for different countries. The ports in these countries are scored on six key criteria: (1) efficiency of the clearance process (i.e., speed, simplicity and predictability of formalities) by border control agencies, including customs; (2) quality of trade- and transport-related infrastructure (e.g., ports, railroads, roads, information technology); (3) ease of arranging competitively priced shipments; (4) competence and quality of logistics services (e.g., transport operators, customs brokers); (5) ability to track and trace consignments; (5) timeliness of shipments in reaching their destination within the scheduled or expected delivery time.

Naturally, the performance of dry ports is measured by their ability to handle goods much like the seaports that they work with. Cezar-Gabriel (2010) [10] argued that the performance assessment of dry ports is not different from seaports in terms of throughput, rate of fast movers and non-stackable goods moving UTE, average storage time of fast movers and average storage time of slow movers. Although Cezar-Gabriel (2010) [10] recognised that dry ports could have good effects on the environment in terms of GHG emission reduction, creation of new processes and new jobs, they argued that it is important to have a measure of the performance of dry ports using an integrated key performance. Bichou and Gray (2004) [11] suggested an integrated approach of different processes and functions within ports from an operational and efficiency point of view but did not include sustainability or environmental burden as part of the measurement. Other research in comparative port performance studies (e.g., Feng et al. 2012) [12] has provided insight on improving port performance mainly on directly comparing operational factors that improve efficiency for customer services and goods handling. Gogas, Adamos and Nathanail (2016) [13] assessed the performance of intermodal freight transport terminals in Thessaloniki using a multi-criteria tailored-KPI assessment framework where environmental burden and safety were assessed as part of the overall management policy with a weightage of 15\%. Morales-Fusco et al. (2016) [14] used a non-parametric data envelope analysis method to compare the efficiency of ports incorporating environmental procedures as an element of risk management and selective controls.

Acciaro (2015) [15] reviewed the corporate and social responsibility (CSR) strategies of 10 ports around the world and found that promoting environmental awareness can also be a source of competitive advantage. The drivers of CSR in ports include ecological and environmental pressures, pressures from local communities and stakeholders, customer retention and true logistics value creation. It was found that the selection of the focus for CSR differs in these ports.

Other researchers have gone beyond an integrated measure for ports and looked at the close relationship between dry port performance and sustainability performance as part of the success factors. Roso (2007) [16] measured the benefits of implementing a dry port by modelling and simulation and found that dry ports have $25 \%$ lower GHG emissions than equivalent seaports and also found that traffic congestion and truck queues and waiting times are significantly reduced. However, Roso (2007) [16] mentioned this depends on the level of service and infrastructure at the intermodal stations, which are also important determining factors. This was supported by the work of Bask et al. (2015) [17] who studied two dry ports in Northern Europe and found that the development of the dry port over time will influence the ability of the seaport-dry port system to take on increases in volumes. Haralambides and Gujar (2012) [18] argued that due to intense competition, the pursuit of supply chain efficiency could significantly alter environmental impacts and argued for a balance. They proposed a model using data envelopment analysis (DEA) to show how the desirable and undesirable effects of dry ports can be balanced.

El-Berishby, Rügge and Scholz-Reiter (2013) [19] argued that green logistics must be an integral part of a sustainable company. There could be internal barriers for the company to initiate green issues, 
and this can arise from the high investment or implication costs, lack of financial or human resources, and lack of knowledge or skills in-house. External barriers can involve limited access to technology that reduces environmental impact, lack of interest or support of customer or transport/logistics suppliers/partners, lack of a government support system, market competition and uncertainty. To realise this idea, obstacles such as inefficient infrastructure, poor schedules, lack of comfort and high prices must be eliminated.

Black et al. (2018) [20] set out a list of important success factors in the establishment of a dry port: emission reduction, railway connection, and a shift from road to rail. They studied the sustainability issues on double-stacked trains and warehousing related to the Moorebank dry port. They found that dry port success depends on both location that is more economically efficient and access to interface in the land port.

A more recent development in dry ports is the concept of synchro modal transportation where the use of innovative technology provides solutions towards the integrated use of different transport modes, which considers real-time flexibility, and which is demonstrated through the SYNCHRO-NET project (Giusti et al. 2019) [21]. In this project, the supply chain is optimised through environmentally friendly practices in long haul shipping using both synchro-modality and slow/smart steaming. In slow/smart steaming, the cargo ships are operated at significantly lower speeds than their design speeds to achieve fuel cost reduction and lower greenhouse gas emissions. Synchro modal transport also considers the stakeholders' requirements to provide a strategy that can incorporate slow steaming to reduce the environmental burden (Perboli 2017) [22].

\subsection{How is Sustainability in Ports Quantified?}

The United Nations UNCTAD's (2016) [23] Port Management series on port performance (p.27) details that scorecards are an important part of port planning for managers. Environmental measures are only a part of the operations' dimensions in the port performance scorecard. Even then, port managers should report on how they are managing environmental issues. There are two types of performance measures in this operations dimension: measures that indicate the existence of recognised international management protocols, which can be captured in a simple survey return, and measures of the relative emission levels of different pollutants in the air, water and soil, and of the impact of noise on local communities. In general, this is costly and technically difficult.

A comprehensive list of transport sustainability indicators identified in previous studies (Table 1) was presented by Reisi et al. (2014) [24]. These indicators have been used to quantify both the determinants of sustainability and the final impacts. They reported that much of the literature does not distinguish between these two. They also argued that using too many indicators is inappropriate and complex for decision making because of their hard interpretation, but integrating different indicators into a single index is useful. They applied some selection criteria to identify a list of indicators that can be used to quantify transport sustainability in Melbourne. Nine sustainability indicators related to urban transport (Table 2) were selected and a composite transport sustainability index was developed. Combined principle component analysis/factor analysis (PCA/FA) was applied for weighing indicators. Although this index was not specifically developed for dry ports but urban transport systems in general, it highlights some of the important considerations for quantifying transport sustainability.

Schipper, Vreugdenhila and de Jonga (2017) [25] compared the long-term vision and port plans against a set of social, economic and environmental KPIs to compare sustainability in long-term port plans. Correlating a wide set of environmental, social, and economic parameters highlighted the heterogeneity, representativeness and applicability of the available data for interpretation. However, the lack of generalised, publicly available environmental data hinders reliable and objective analysis. They argued for the development of a worldwide standard set of KPIs for ports, which can then be used by ports to formulate long-term plans and for evaluating the progress realised by ports on the three main aspects of people, planet and prosperity. It is of importance that ports worldwide develop and adopt a uniform set of KPIs to assess and develop port operations, wealth, social welfare and environmental impacts. Only in 
that way can port plans be developed based on an appropriate set of quantifiable KPIs and can plans and results realised be compared directly to the performance of other ports.

Table 1. Transport sustainability indicators (Source: Reisi et al., 2014) [24].

\begin{tabular}{|c|c|c|}
\hline Aspect & Indicators & Determinants \\
\hline \multirow{5}{*}{ Environmental } & GHG emission & $\begin{array}{l}\text { - Vehicle kilometre travelled (VKT) by car } \\
\text { - Passenger kilometre travelled (PKT) by } \\
\text { public transport } \\
\text { - Mode share }\end{array}$ \\
\hline & Other air pollutants & $\begin{array}{l}\text { - VKT } \\
\text { - PKT by public transport } \\
\text { - Mode share }\end{array}$ \\
\hline & Energy use & $\begin{array}{l}\text { - VKT } \\
\text { - PKT by public transport } \\
\text { - Mode share }\end{array}$ \\
\hline & Population exposed to noise & - Traffic volume \\
\hline & Land consumption for transport & $\begin{array}{l}\text { - Land use mix } \\
\text { - Length of railways and main road } \\
\text { - Length of cycling and walking pass }\end{array}$ \\
\hline \multirow{4}{*}{ Social } & $\begin{array}{l}\text { Fatalities and injuries of traffic } \\
\text { accidents per capita }\end{array}$ & - Vehicle ownership \\
\hline & $\begin{array}{l}\text { Accessibility to facilities and } \\
\text { public transport }\end{array}$ & $\begin{array}{l}\text { - Railway and main road length } \\
\text { - Proportion of residents with public transit } \\
\text { services within } 500 \mathrm{~m}\end{array}$ \\
\hline & $\begin{array}{l}\text { Satisfaction of citizens and variety } \\
\text { and quality of transport options }\end{array}$ & $\begin{array}{l}\text { - Quality of transport for disadvantaged, } \\
\text { disabled, children, non-driver } \\
\text { - Quality of pedestrian and bicycle } \\
\text { environment }\end{array}$ \\
\hline & $\begin{array}{l}\text { Fatality and injuries resulted from } \\
\text { air pollution }\end{array}$ & - \\
\hline \multirow[t]{3}{*}{ Economic } & $\begin{array}{l}\text { Household expenditure allocated } \\
\text { to transport }\end{array}$ & $\begin{array}{l}\text { - Cost of parking } \\
\text { - Fuel price } \\
\text { - Commute costs }\end{array}$ \\
\hline & Accident cost & - \\
\hline & Transport emission costs & $\begin{array}{l}\text { - VKT } \\
\text { - Modal split }\end{array}$ \\
\hline
\end{tabular}

Table 2. Selected transport sustainability indicators (Source: Reisi et al., 2014) [24].

\begin{tabular}{cc}
\hline Selected Indicators & Unit \\
\hline Transportation environmental indicators \\
\hline $\begin{array}{c}\text { Depletion of non-renewable resources } \\
\text { GHG emissions }\left(\mathrm{CO}_{2-\mathrm{e}}\right)\end{array}$ & $\begin{array}{c}\text { Litres of crude oil per household annually } \\
\text { Kilograms per household annually }\end{array}$ \\
Other air pollutants $\left(\mathrm{CO}, \mathrm{NO}_{2}, \mathrm{PM}_{10}\right)$ & Kilograms per household annually \\
Land consumption for transport & Square metres per household \\
\hline Transportation social indicators \\
\hline Accessibility & Score between 0 and 1 \\
Fatalities and injuries related to traffic accidents & Persons per household annually \\
Mortality effects of air pollutants & Persons per household annually \\
\hline Transportation economic indicators \\
\hline Car ownership costs & Dollars (\$) per household annually \\
Vehicle and general costs of accidents & Dollars (\$) per household annually
\end{tabular}


Awad-Núñez et al. (2016) [26] presented a method for scoring the sustainability using multi-decision criteria analysis of dry ports in Spain based on the fact the economic, social and environmental implications are closely tied in with the geographic location of the dry port. Forty-one variables were grouped into 17 factors. Examples of these factors include concerns for the natural environment and the urban environment. Perera and Abeysekara (2016) [27] studied Sri Lankan container terminals, which are also used in dry ports. They suggested that the balanced scorecard is a good technique to incorporate environmental sustainability into the set of prioritised KPIs to monitor company performance. This view was also shared by Di Vaio et al. (2018) [28] who studied Italian seaports and argued that the balanced scorecard can be used to develop extended managerial KPIs for competitive green ports as part of the internal processes. Having KPIs developed in this manner allows for greater managerial control.

Table 3 shows some of the sustainability initiatives implemented by Australian dry ports and international large dry ports. This survey was done by collecting data from the dry ports' websites. Some of the ports have specific sustainability targets, and this is indicated in the last column.

Table 3. Selected major dry ports and their sustainable initiatives.

\begin{tabular}{|c|c|c|c|}
\hline Inland Port & Location & Sustainable Initiatives & KPIs \\
\hline Moorebank & NSW & $\begin{array}{l}\text { Installation of renewable energy } \\
\text { Use of passive design techniques } \\
\text { Highly efficient HVAC } \\
\text { Use of electric wherever possible and not LPG } \\
\text { Installation of rainwater } \\
\text { On-site detection basins } \\
\text { Flush kerbs } \\
\text { Air cooled air-conditioning equipment } \\
\text { Low toxic materials } \\
\text { Dedicated waste recycling area } \\
\text { Comprehensive waste recycling } \\
\text { Cyclist facilities } \\
\text { Sustainability criteria }\end{array}$ & $\begin{array}{l}\text { Generate } 50,000 \mathrm{MWh} / \mathrm{Yr} \text {. from } \\
\text { renewable sources } \\
\text { Reduce } \mathrm{CO}_{2} \text { emissions by } 110,000 \mathrm{t} \\
\text { Cut more than } 3000 \text { heavy truck } \\
\text { movements from Sydney }\end{array}$ \\
\hline Somerton & VIC & $\begin{array}{l}\text { Climate change and energy } \\
\text { Water } \\
\text { Biodiversity }\end{array}$ & $\begin{array}{l}\text { Reduce energy intensity by } 39 \% \\
\text { Reduce } \mathrm{CO}_{2} \text { emissions by } 57 \% \\
\text { (customers) } \\
\text { Improve recycling from } 29 \% \text { to } 40 \% \\
\text { Reduce water intensity by } 44 \%\end{array}$ \\
\hline Duisburg & Germany & $\begin{array}{l}\text { Sustainability } \\
\text { Noise } \\
\text { Light and water protection } \\
\text { Frugal use of raw materials } \\
\text { Reduction of pollutants } \\
\text { Modern waste management } \\
\text { Own solar facility } \\
\text { Reduction of consumption of fossil fuels } \\
\text { Own solar facility }\end{array}$ & $\begin{array}{l}\text { Reduce no of trucks by } 100000 \text { a year } \\
\text { Traffic management system that } \\
\text { reduces emissions by } 30 \%\end{array}$ \\
\hline Centrepoint & USA & $\begin{array}{l}\text { Energy efficiency } \\
\text { Roof retrofits } \\
\text { Warehouse lot light fixture replacement } \\
\text { Solar panels } \\
\text { Hydrogen fuel cells } \\
\text { Brownfield development } \\
\text { Previously contaminated properties } \\
\text { USGBC LEED certified buildings }\end{array}$ & NA. \\
\hline
\end{tabular}

Source: Moorebank (2017) [29], Somerton (2018) [30], Duisburg (2018) [31] and Centrepoint (2019) [32].

\subsection{Goal Setting and Key Performance Indicators}

Kaplan and Norton (1993) [33] first recognised the importance of measures on performance. The ability to measure is an essential part of the overall strategy of any organisation. Using their scorecard approach - which measures an organisation on four different perspectives of financial 
performance, operational performance, customers, and people-they argue that these can help track progress towards a corporate goal. These measurements should also be linked to strategies. Using incorrect measures can encourage inappropriate activities and inhibit performance in the company. Key performance indicators (KPIs) are, therefore, tied to a team's collective effort that can enhance performance that contributes to the goals. They are regarded as the centrepiece of the new organisational culture (Parmenter 2007) [34].

The idea of an established KPI system is also the basis of the goal-setting theory. Locke and Latham $(1993,2004)[35,36]$ argued that there are links between performance management and motivational theory. Being conscious of goals affects actions and stimulates a response in terms of behaviour. However, this theory can only be effectively applied when people as individuals have control over their actions. In addition, Locke (2004) [37] also discussed the potential of goal conflicts, which can lead to incompatible actions. Alignment of both individual and corporate goals is important, as well as the alignment of goals of different subunits of the organisation.

KPIs are an important way of engaging employees. An example of this can be found in the concept of 'Hoshin Kanri' (a management method used for reinforcing strategic work) or strategy deployment, which is a part of the Toyota production system (Akao 2004) [38]. Strategy deployment translates strategy into goals for smaller business units. Long-term visions and strategies are broken into smaller chunks for departments and, in turn, decomposed into smaller bits that are meaningful for smaller work units and individuals. The decomposed goals would add up to in reverse the total strategy (Akao 2004) [38]. One of the purposes of formulating meaningful goals for the smaller organisational units is to maintain a line of sight to the top management visions and goals.

Another example of the important use of KPIs in strategy formulation is the Victorian government's Department of Treasury and Finance (DTF) processes for the initial phases of project initiation. In the strategic assessment phase of any project, organisational units are required to map the investment logic and benefits using the investment logic maps and benefits map (DTF 2018) [39]. The benefits of undertaking the projects are mapped onto current and expected indicators. This is a good example of creating good connection between vision and strategy.

\subsection{Engaging Employees in Sustainability in Dry Ports}

In the literature review, we found that dry ports and ports in general can use a variety of measures to track performance and progress. Implementing a specific set of KPIs can influence employees' behaviours in that area. For example, emphasising logistics performance may mean that employees may see environmental and sustainability as having less importance than operational matters. Bentaleb et al. (2015) [40] surveyed works done by other researchers on performance measurements and formulated a framework that has KPIs in different phases of the transport process. The World Bank also has recommendations for KPIs of ports and freight terminals (Kruk and Donner 2009) [41]. Most of these focus on the areas of reliability, quality and time, but nothing is directly related to environment or sustainability while recognising that dry ports are a less harmful means of transporting goods.

Incorporating sustainability as part of a larger set of KPIs may be a solution. Martín et al. (2016) [42] proposed a set of KPIs for dry ports based on the major decision-making areas as operations, finance, quality, environment and safety with three viewpoints. They proposed that the operator measures the energy consumption per handled unit and the public body or regulator monitors the emissions $\left(\mathrm{CO}, \mathrm{NO}_{X}, \mathrm{SO}_{X}\right.$ and $\left.\mathrm{PMs}\right)$ and noise levels.

However, the pursuit of sustainability may rank lower in importance for private organisations. In a study of Indonesian and Australian port operators, Daghlas, Hui and Duffield (2018) [43] found that the private sector with profit motives tend to rank sustainability as lower in importance when compared to other operational functions. Therefore, it is essential to educate people on the importance of sustainability when evaluating or initiating infrastructure projects. It is especially important for dry ports where terminals, warehouses, and infrastructure for road-rail connectivity have to be built on areas where people could be living. 


\section{Discussion}

\subsection{The Challenges and the Gaps}

The ownership and operating structures of dry ports can be quite complex with large logistics companies operating the intermodal stations, private developers owning business parks and warehousing facilities around the complex and private owners becoming tenants at these business parks. Private companies sometimes see the need to conform to environmental regulations and the implementation of sustainability measures as a burden and necessary evil.

Secondly, tackling sustainable challenges requires different measures from the different stakeholders in the dry ports. As can be seen from Table 3, there are certain measures that are best determined strategically by the developers or owners. Two examples include the use of renewable energy technologies and the types of materials used in heat insulation of the factories. At a higher level, Vejvar et al. (2018) [44] observed that dry ports respond to pressures on sustainability via acquiescence (forcing habits, imitating and complying). They are also partly compromised by pacifying and bargaining and sometimes defy by attacking or dismissing these pressures. On the other hand, employees who are working on the dry ports may be best suited to tackle tasks such as operational (demand side) use of electricity, gas and fuels, water usage and management, waste (solid, liquid and air born) management, management of air quality and GHG emissions that could arise from the use of equipment on site. Noise emissions could be another issue that could be controllable by the operators of the park. It is, therefore, important to engage with the various stakeholders to develop a set of KPIs that is acceptable. This buy-in is extremely important to the process. KPI development can be an extension of the balanced scorecard approach (Kaplan \& Norton 1993) [33] as evidenced by the studies done by Perera and Abeysekara (2016) [27] and Di Vaio et al. (2017) [28].

Thirdly, in setting KPIs, it is important to note the dynamics of nature (leading, lagging and coincident) in them. The choice of the indicator is important as they relate to the sustainability performance of an organisation in time. Leading indicators are predictors of sustainability, lagging indicators show the performance at some point in time in the past, and coincident indicators show sustainability performance at the time of measurement (Herriot 2016) [45].

Fourthly, given the complex and operational structures, the use of contractual and legal means to bind the operators to measure these under their contracts is needed. An advanced intermodal system, i.e., seaport-dry port system, is complex where there are many stakeholders in both the private and public sectors (Roso, 2008) [46]. Wu and Haasis (2018) [47] proposed an integrated freight village involving supermarkets and farmers' co-ops in the dry port as a means to deal with sustainability issues.

\subsection{An Example of Sustainability at a Dry Port: Melbourne's Somerton Intermodal Station}

The port of Somerton in Victoria is $26 \mathrm{~km}$ north of Melbourne and is located about $8 \mathrm{~km}$ from the airport and just $2 \mathrm{~km}$ from The Melbourne Wholesale Market, which is the centre for distribution of agricultural produce just north of Melbourne. Like the Moorebank intermodal terminal in Sydney, it has links to the inland rail. There is a business park right next to it with full warehousing and distribution facilities. The location is very conducive to being a sustainable dry port in many aspects. The developer at the Somerton intermodal terminal is committed to sustainability (Somerton Business Park 2018). It has put in place initiatives for using renewable energy technologies, as well as the use of heat insulation materials to reduce energy consumption. As the business park will attract many high-profile tenants in the food and agribusiness, jobs will also be created in the warehousing facilities as well as the intermodal terminals that move freight away from the seaport.

The Somerton Business Park is home to many tenants who may have their own sustainability practices. While it is possible to bind the tenants to sustainable performance in legal contracts (Roso 2008) [46], it may be difficult to monitor the ongoing sustainability practices or even their behaviour or responses to sustainability pressures described by Wu and Haasis (2018) [47]. The developers at the Port of Somerton intend to jointly develop sustainability KPIs with their stakeholders, especially 
their tenants. Sustainability KPIs can be an extended version of the balanced scorecard and used to support specific aspects of the tenants' businesses (Kaplan \& Norton (1993) [33], Perera \& Abeysekara (2016) [27] and Di Vaio et al. (2017) [28].

\section{Conclusions}

Dry ports offer good potential for solving the problems of space shortage at seaports and the traffic congestion around seaports. They also bring about the promise of reducing GHG emissions and lowering the environmental impacts by removing trucks from the roads around seaports. However, it is important to note that these inland ports may be owned and operated by private organisations with profit objectives. In the pursuit of good connectivity and supply chain operational efficiency, it is also important to include meaningful sustainability KPIs. The involvement of employees is essential for change management programs or sustainability initiatives to work. The structure of dry ports may mean that different parts of the supply chain may have to work with different targets to achieve an overall sustainability target. These targets should be translated or deployed into meaningful KPIs. Only then can we engage them as part of the new organisational culture.

Author Contributions: Conceptualisation, F.K.P.H.; research method, F.K.P.H. and L.A.; formal analysis, F.K.P.H.; data curation, F.K.P.H. and L.A.; writing-F.K.P.H., L.A. and C.F.D.; writing-review and editing, C.F.D.; funding acquisition, C.F.D.

Funding: The financial support received from the Australia-Indonesia Centre is gratefully acknowledged along with the background funders of the Department of Foreign Affairs and Trade, Australia, DIKTI in Indonesia.

Acknowledgments: Supports from The University of Melbourne, Universitas Gadjah Mada and the Universitas Indonesia and providing staff time to undertake the strategic research project on "Efficient Facilitation of Major Infrastructure Projects" are acknowledged.

Conflicts of Interest: The authors declare no conflict of interest.

\section{References}

1. UNESCAP. Cross-Cutting Issue for Managing Globalization Related to Trade and Transport: Promoting Dry Ports as a Means of Sharing the Benefits of Globalization with Inland Locations; UNESCAP: Bangkok, Thailand, 2006.

2. Nguyen, L.C.; Notteboom, T. The relationships between dry port and regional port-hinterland settings: Findings for a global sample of dry ports. Marit. Policy Manag. 2019, 46, 24-42. [CrossRef]

3. Beresford, A.; Pettit, S.; Xu, Q.; Williams, S. A study of dry port development in China. Econ. Logist. 2012, 14, 73-98. [CrossRef]

4. Roso, V.; Woxenius, J.; Lumsden, K. The dry port concept: Connecting container seaports with the hinterland. J. Geogr. 2009, 17, 338-345. [CrossRef]

5. Roso, V.; Lumsden, K. The dry port concept: Moving seaport activities Inland? J. Transp. Geogr. 2009, 17, 338-345. [CrossRef]

6. US EPA-U.S. Environmental Protection Agency. Inventory of U.S. Greenhouse Gas Emissions and Sinks: 1990-2012. 2014. Available online: http://www.epa.gov/climatechange/Downloads/ghgemissions/US-GHGInventory-2014-Main-Text.pdf (accessed on 2 March 2019).

7. Roso, V.; Brnjac, N.; Abramović, B. Inland Intermodal Terminals Location Criteria Evaluation: The Case of Croatia. Transp. J. 2015, 54, 496. [CrossRef]

8. Nunez, S.A.; Cancelas, N.G.; Orive, A.C. Setting of factors considered when determining the location area of a dry port and its hierarchies through a Delphi methodology. Revista De Transporte Y Territorio 2015, 13, 100-121.

9. Wiegmans, B.; Witte, P.; Spit, T. Characteristics of European inland ports: A statistical analysis of inland waterway port development in Dutch municipalities. Transp. Res. Part A 2015, 78, 566-577. [CrossRef]

10. Cezar-Gabriel, C. Performance assessment in operating dry ports. In Annals of Faculty of Economics; University of Oradea: Oradea, Romania, 2010; Volume 1, pp. 934-938.

11. Bichou, K.; Gray, R. A logistics and supply chain management approach to port performance measurement. Marit. Policy Manag. 2004, 31, 47-67. [CrossRef] 
12. Feng, M.; Mangan, J.; Lalwani, C. Comparing port performance: Western European versus Eastern Asian ports. Int. J. Phys. Distrib. Logist. Manag. 2012, 42, 490-512. [CrossRef]

13. Gogas, M.; Adamos, G.; Nathanail, E. Assessing the performance of intermodal city logistics terminals in Thessaloniki. Transp. Procedia 2017, 24, 17-24. [CrossRef]

14. Morales-Fusco, P.; Saurí, S.; Lekka, A.M.; Karousos, I. Assessing customs performance in the Mediterranean ports. KPI selection and Best practices identification as part of the MEDNET project. Transp. Res. Procedia 2016, 18, 74-383. [CrossRef]

15. Acciaro, M. Corporate responsibility and value creation in the port sector. Int. J. Logist. Appl. 2015, 18, $291-311$. [CrossRef]

16. Roso, V. Evaluation of the dry port concept from an environmental perspective: A note. Transp. Res. Part D Transp. Environ. 2007, 12, 523-527. [CrossRef]

17. Bask, A.; Roso, V.; Andersson, D.; Hämäläinen, E. Development of seaport-dry port dyads: Two cases from Northern Europe. J. Geogr. 2014, 39, 85-95. [CrossRef]

18. Haralambides, H.; Gujar, G. On balancing supply chain efficiency and environmental impacts: An eco-DEA model applied to the dry port sector of India. Econ. Logist. 2012, 14, 122-137. [CrossRef]

19. El-Berishy, N.; Rügge, I.; Scholz-Reiter, B. The Interrelation between Sustainability and Green Logistics. IFAC Proc. Vol. 2013, 46, 527-531. [CrossRef]

20. Black, J.; Roso, V.; Marušić, E.; Brnjac, N. Issues in Dry Port Location and Implementation in Metropolitan Areas: The Case of Sydney, Australia. Trans. Sci. 2018, 7, 41-50. [CrossRef]

21. Giusti, R.; Iorfida, C.; Li, Y.; Manerba, D.; Musso, S.; Perboli, G.; Tadei, R.; Yuan, S. Sustainable and De-Stressed International Supply-Chains Through the SYNCHRO-NET Approach. Sustainability 2019, 11, 1083. [CrossRef]

22. Perboli, G.; Musso, S.; Rosano, M.; Tadei, R.; Godel, M. Synchro-Modality and Slow Steaming: New Business Perspectives in Freight Transportation. Sustainability 2017, 9, 1843. [CrossRef]

23. UNCTAD. Port Management Series Volume 4 Port Performance; United Nations: New York, NY, USA, 2016.

24. Reisi, M.; Aye, L.; Rajabifard, A.; Ngo, T. Transport sustainability index: Melbourne case study. Ecol. Indic. 2014, 43, 288-296. [CrossRef]

25. Schipper, C.; Vreugdenhil,H.; De Jong, M. A sustainability assessment of ports and port-city plans: Comparing ambitions with achievements. Transp. Res. Part D Transp. Environ. 2017, 57, 84-111. [CrossRef]

26. Awad-Núñez, S.; Soler-Flores, F.; González-Cancelas, N.; Camarero-Orive, A. How should the Sustainability of the Location of Dry Ports be Measured? Transp. Procedia 2016, 14, 936-944. [CrossRef]

27. Perera, M.P.A.; Abeysekara, B. Defining KPIs to measure eco-sustainable performance at container terminals in Sri Lanka. In Proceedings of the Moratuwa Engineering Research Conference (MERCon), Moratuwa, Sri Lanka, 5-6 April 2016.

28. Di Vaio, A.; Varriale, L.; Alvino, F. Key performance indicators for developing environmentally sustainable and energy efficient ports: Evidence from Italy. Energy Policy 2018, 122, 229-240. [CrossRef]

29. Moorebank Business Park. Sustainability. 2017. Available online: http://qubemlp.com.au/about/ sustainability/ (accessed on 3 March 2019).

30. Somerton Business Park. Sustainability/Environment. 2018. Available online: https://www.gpt.com.au/ index.php/sustainability/environment (accessed on 3 March 2019).

31. Duisburg Port Information. Environment and Resources. 2018. Available online: https://www.duisport.de/ unternehmen/unsere-verantwortung/mensch-mitarbeiter/?lang=en (accessed on 2 March 2019).

32. Centrepoint. Intermodal White Paper. Available online: https://centerpoint.com/expertise/industrial-realestate-development/sustainable-industrial-real-estate-development/ (accessed on 2 March 2019).

33. Kaplan, R.S.; Norton, D.P. Putting the Balanced Scorecard to Work; Harvard Business: Brighton, MA, USA, 1993.

34. Parmenter, D. Key Performance Indicators-Developing, Implementing and Using KPI's, 3rd ed.; Wiley: Hoboken, NJ, USA, 2007.

35. Locke, E.A.; Latham, G.P. Self-regulation through Goal Setting. Organ. Hum. Decis. Process 1993, 50, $212-247$.

36. Locke, E.A.; Latham, G.P. What Should We Do about Motivation Theory? Six Recommendations for the Twenty-First Century. Acad. Manag. 2004, 29, 388.

37. Locke, E.A. Work Motivation; Elsevier: Amsterdam, The Netherlands, 2004.

38. Akao, Y. Hoshin Kanri: Policy Deployment for Successful TQM; Productivity Press: New York, NY, USA, 2004.

39. DTF-Dept of Treasury and Finance. 2018. Available online: https://www.dtf.vic.gov.au/investmentmanagement-standard/ims-workshops-and-examples (accessed on 1 March 2019). 
40. Bentaleb, F.; Mabrouki, C.; Semma, A. Key Performance Indicators Evaluation and Performance Measurement in Dry Port-Seaport System: A Multi Criteria Approach. J. ETA Sci. 2015, 3, 97-116. [CrossRef]

41. Kurk, C.B.; Donner, M. Freight Transport Toolkit_Ports and Waterborne Freight; The Transport Research Group, Department for International Development, The World Bank: Washington, DC, USA, 2009.

42. Enrique Martín, M.; Ángel, D.; Gisela, S. Study of the state of the art and description of KPI and KRI of terminals, hinterland mobility and rail network. In European Union's Horizon 2020 Research and Innovation Programme Final Report; Intermodal Europe: Rotterdam, The Netherlands, 2016.

43. Daghlas, H.; Hui, F.K.P.; Duffield, C. The importance of environmental sustainability to obtain finance for port developments in Australia and Indonesia. In Proceedings of the 42nd AUBEA Conference 2018: Educating Building Professionals for the Future in the Globalised World, Singapore, 27 September 2018.

44. Vejvar, M.; Lai, K.-H.; Lo, C.K.; Fürst, E.W. Strategic responses to institutional forces pressuring sustainability practice adoption: Case-based evidence from inland port operations. Transp. Res. Part D Transp. Environ. 2018, 61, 274-288. [CrossRef]

45. Herriot, S.R. Metrics for Sustainable Business: Measures and Standards for the Assessment of Organisations; Routledge: New York, NY, USA, 2016.

46. Roso, V. Factors influencing implementation of a dry port. Int. J. Phys. Distrib. Logist. Manag. 2008, 38, 782-798. [CrossRef]

47. Wu, J.N.; Haasis, H.D. The freight village as a pathway to sustainable agricultural products logistics in China. J. Clean. Prod. 2018, 196, 1227-1238. [CrossRef]

(C) 2019 by the authors. Licensee MDPI, Basel, Switzerland. This article is an open access article distributed under the terms and conditions of the Creative Commons Attribution (CC BY) license (http://creativecommons.org/licenses/by/4.0/). 